\title{
First record of the ragged-tooth shark, Odontaspis ferox (Risso, 1810), in the Venezuelan Caribbean
}

\author{
Rafael Tavares ${ }^{1 *}$ (D), Leonardo Sanchez ${ }^{1,2}$ and Jose Manuel Briceño ${ }^{3}$
}

\begin{abstract}
One specimen of the ragged-tooth shark, Odontaspis ferox, was caught by a commercial shark fishery to the north of Cape Codera $\left(10^{\circ} 56^{\prime} \mathrm{N}, 66^{\circ} 02^{\prime} \mathrm{W}\right.$ ), northeastern Venezuela. The specimen (sex unidentified, $\sim 180 \mathrm{~cm} \mathrm{TL}, \sim 30$ $\mathrm{kg}$ ) was identified on the basis of its dry jaw and characteristic dentition: which comprise teeth moderately large, with prominent narrow cusps and two or three pairs of lateral cusplets. This is the first record of $O$. ferox in the Venezuelan Caribbean, and this finding complements the knowledge of geographic distribution of this rare species in the Western Central Atlantic.
\end{abstract}

Keywords: Distribution, Elasmobranch, Species, Taxonomy

\section{Introduction}

The dramatic decline in the abundance of sharks, together with a greater understanding of their ecological importance and the high vulnerability of some of these species to extinction have attracted increasing scientific concern in recent years (Baum and Myers 2004; Ferretti et al. 2010; Dulvy et al. 2014; Heupel et al. 2014). Sharks and rays are among the marine organisms under direct threat from overfishing either as bycatch or in direct fisheries (Jackson et al. 2001; Baum and Myers 2004; Clarke et al. 2007). Knowledge about biodiversity and species distribution is crucial for the development of management and conservation plans, in order to contribute to the recovery and sustainability of shark populations. In the case of rare species, their occurrence may be under-reported, which can have management implications since many shark species are conservationdependent (Santander-Neto et al. 2011).

The ragged-tooth shark, Odontaspis ferox, is an uncommon and poorly known species, widely distributed in warm-temperate and tropical seas of continental and insular shelves and upper slopes (Compagno 2001; Fergusson et al. 2008). It is a bulky shark with a long and

\footnotetext{
* Correspondence: rafaeltavares2569@gmail.com

${ }^{1}$ Centro para la Investigación de Tiburones (CIT), Av. Don Bosco, Qta ABC, No.

10, La Florida, Distrito Capital, Caracas 1050, Venezuela

Full list of author information is available at the end of the article
}

conical snout and mouth very long and angular; five medium to large gill slits, all anterior to the pectoral fin; two dorsal fins, the first dorsal large and situated closer to the pectoral fins, and the second dorsal fin slightly smaller than the first dorsal fin. The dentition of this species is very characteristic, with teeth moderately large, prominent narrow cusps and two or three pairs of lateral cusplets; and body colour is typically brownishgrey dorsally and lighter below with darker dusky spots along the sides (Compagno 2001). Odontaspis ferox is a large shark with a maximum total length around $400 \mathrm{~cm}$ TL in both sexes, and a size at birth of about $100 \mathrm{~cm} \mathrm{TL}$ (Fergusson et al. 2008).

In the Western Atlantic, its distribution was unknown until the 1990s. The first reports of O. ferox for the Western Atlantic were from Yucatán, Gulf of Mexico (Bonfil 1995), Natal, northeastern Brazil (Menni et al. 1995), and North Carolina, US Atlantic (Sheehan 1998). More recently, this species has been recorded from off South Carolina and Florida, US Atlantic (Ross and Quattrini 2007), Fernando de Noronha Archipelago and Ceará, northeastern Brazil (Garla and Garcia 2008; Santander-Neto et al. 2011), and Barranquilla, Colombian Caribbean (Anguila et al. 2016). Despite the recent increase in reports of $O$. ferox in the region has not hitherto been reported for the Venezuelan Caribbean (between Colombia and Brazil). Currently, this species is 


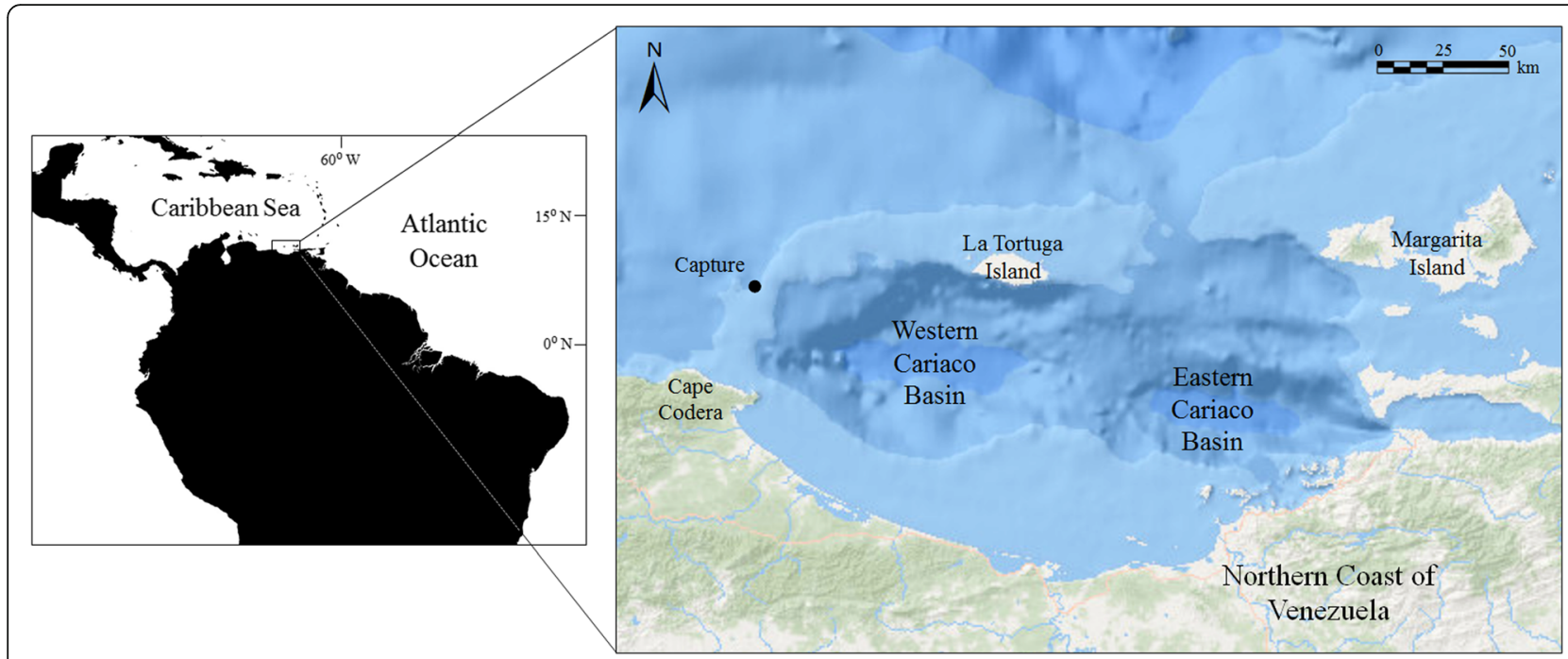

Fig. 1 Geographical location of the capture of the ragged-tooth shark, Odontaspis ferox, by the commercial shark fishery in the Venezuelan Caribbean

listed as vulnerable in the IUCN Red List of Threatened Species due to its rarity, very low fecundity and high vulnerability to exploitation (Graham et al. 2016).

\section{Capture location}

In April 2018, an uncommon shark was captured by a commercial shark fishery, at a depth of $80 \mathrm{~m}$, approximately $38 \mathrm{~km}$ north of Cape Codera $\left(0^{\circ} 56^{\prime} \mathrm{N}, 66^{\circ} 02^{\prime} \mathrm{W}\right)$ in the Venezuelan Caribbean (Fig. 1). The northeastern region of Venezuela (from Cape Codera to the boundary with Trinidad and Tobago) is under the strong influence of oceanographic and environmental factors, such as a seasonal upwelling system (Rueda-Roa and Muller-Karger 2013) and regional river runoff, including the discharges of the Orinoco River into the Caribbean Sea (Muller-Karger and Varela 1990; McConnell et al. 2009). These events contribute to the high marine productivity by increasing primary production and abundance of fishing resources. In the northeastern region, the salinity fluctuates around $36.6 \%$, and the water temperature oscillates between 20.5

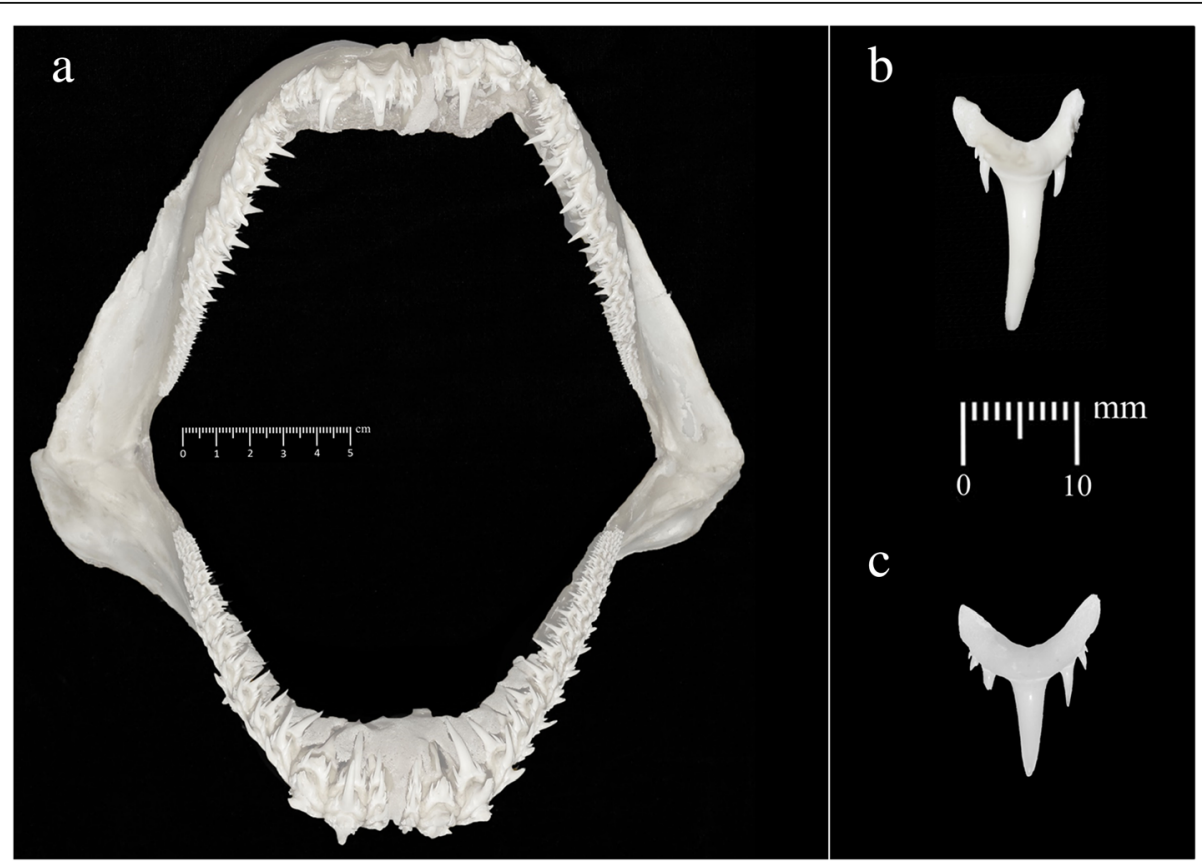

Fig. 2 Material from the ragged-tooth shark, Odontaspis ferox, captured by the commercial shark fishery in the Venezuelan Caribbean: a dry jaw, b anterior tooth [left upper jaw] and $\mathbf{c}$ lateral tooth [left lower jaw] 
and $29.7^{\circ} \mathrm{C}$ during the principal and relaxation upwelling periods, respectively (Castellanos et al. 2002; McConnell et al. 2009).

The fishing boat involved in the capture of the shark comes from the medium-scale artisanal fishing fleet based on Margarita Island, and this particular boat $(13 \mathrm{~m}$ in length, equipped with a central motor of $120 \mathrm{hp}$ ) operates with bottom gillnets (300-600 m long, $3.0 \mathrm{~m}$ deep, 21.0 $\mathrm{cm}$ square mesh) in an extensive area of the northeastern region of Venezuela, from around Margarita Island to Cape Codera and La Tortuga Island. According to the information provided by fishermen, the captured specimen (sex unidentified) measured $\sim 180 \mathrm{~cm}$ total length and weighed $\sim 30 \mathrm{~kg}$. The body colour reported for the specimen was uniformly grey without the apparent presence of dark spots on the back or sides.

\section{Identification}

After the capture, the specimen was immediately eviscerated, stored and later sold by fishermen on Margarita
Island; this precluded taxonomic identification, sex determination and data collection (i.e. morphometric and biological characteristics). However, the specimen was identified to species level on the basis of its dry jaw and dentition characteristics (Fig. 2a). The jaw was donated by the fishermen and deposited in the collection of shark jaws (under the code number CIT 1-037) of the Centro para la Investigación de Tiburones (CIT), Caracas, Venezuela.

The species $O$. ferox can be easily identified by its particular dentition which comprises generally three rows of small intermediate teeth between the upper anterior and lateral tooth rows, and teeth mostly with two or three cusplets on each side of the cusp, characteristics unique to this species (Fig. 2b, c). In order to facilitate comparisons, dentition configuration and teeth measurements of the left upper and lower jaw were graphically represented by using frequency histograms (Fig. 3) according to Garrick (1974). The height of the external teeth (crown height) was taken at the middle of each tooth from the crown-base junction to the apical edge of
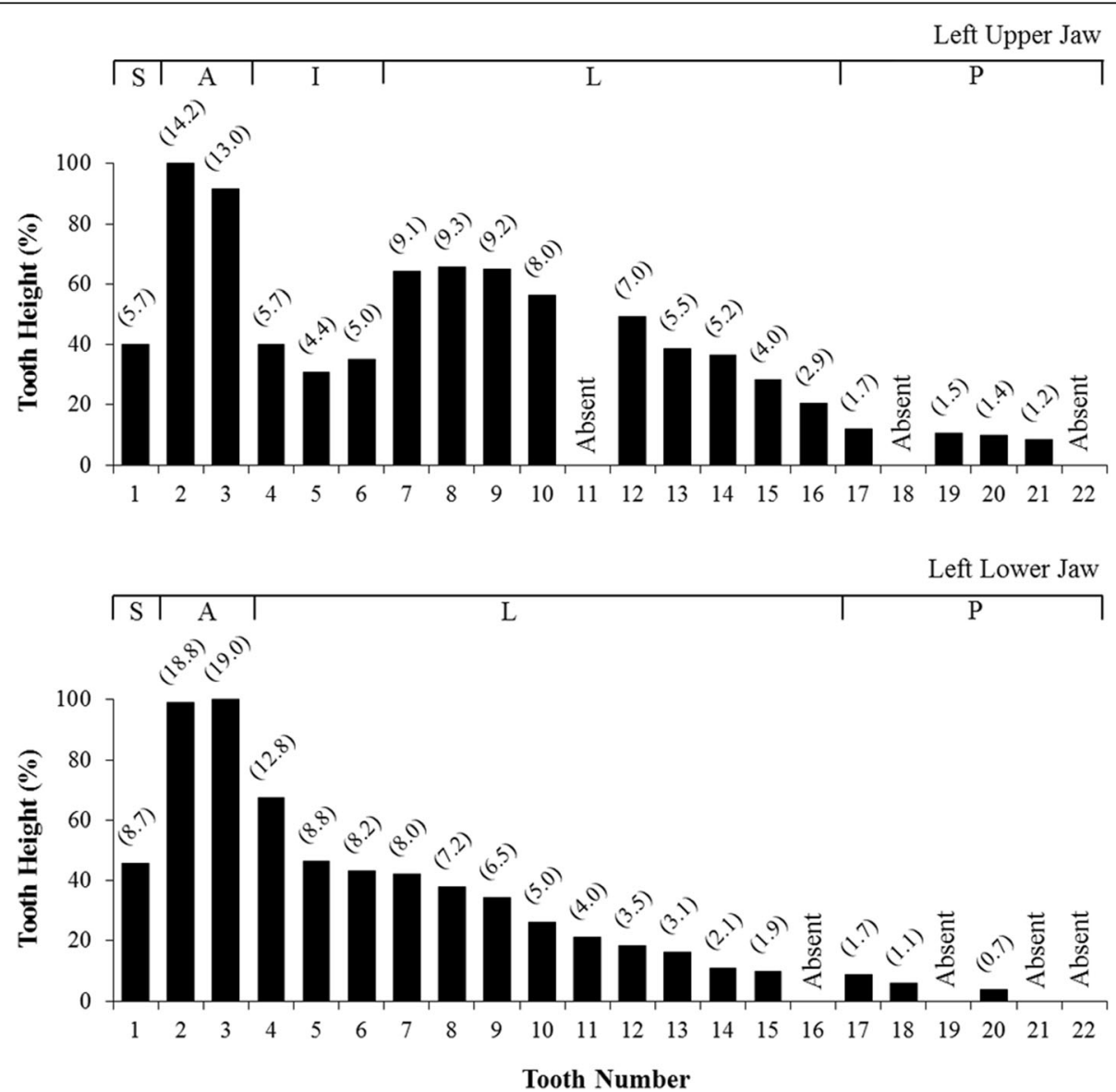

Fig. 3 Height of external teeth of the left upper and lower jaw (expressed as a percentage of height of largest tooth) for ragged-tooth shark, Odontaspis ferox, captured by the commercial shark fishery in the Venezuelan Caribbean. In parenthesis heights of tooth (mm). S, symphyseal; A, anterior; I, intermediate; L, lateral; P, posterior 
the crown. The morphological and meristic characteristics of the dentition of the dry jaw agree with previous descriptions for this species (Compagno 2001; Bonfil 1995; Menni et al. 1995; Sheehan 1998).

\section{Discussion}

This capture of O. ferox near Cape Codera is the first report of the occurrence of this species in the Venezuelan Caribbean and complements knowledge of its range in the Western Central Atlantic. Although this species appears to have a cosmopolitan distribution in the Atlantic, records of its occurrence have been very limited in the tropical region. The paucity of capture records of O. ferox may be attributable to the low relative abundance of this species (Graham et al. 2016) but also to its deep-water habitat out of the depth range of most commercial and traditional fishing operations (Sheehan 1998). Available data indicated that the overall depth range for O. ferox is $10-883 \mathrm{~m}$; however, most specimens have been registered at depths between 200 and $600 \mathrm{~m}$ (Fergusson et al. 2008), reflecting the preference of this species for zones of deep waters generally close to the seabed around islands and outer continental shelves.

According to the maturity size reported for O. ferox (males: $200-250 \mathrm{~cm}$ TL; females: $300-350 \mathrm{~cm}$ TL; Fergusson et al. 2008), the specimen captured $(180 \mathrm{~cm} \mathrm{TL})$ in the Venezuelan Caribbean corresponds to an immature individual. The absence of captures of pregnant females with advanced stages of gestation and newborn individuals has prevented the identification of the nursery grounds of this species through its range of distribution. Fergusson et al. (2008) suggested that nurseries of $O$. ferox are commonly associated with deep offshore habitats on upper continental and insular slopes. The Caribbean Sea comprises a combination of environments (including chain islands, reef systems, submarine basins, and underwater seamounts) that provide a wide variety of habitats for sharks. The capture of a large number of pregnant females and juveniles of oceanic sharks in the Venezuelan Caribbean showed that this tropical region is crucial in the life cycle of this group of fishes (Tavares and Arocha, 2008).

The monitoring of fishing activities is essential to obtain biological information and to increase knowledge of the exploited species. The Venezuelan governmental organizations with responsibility in fishery administration and data collection must make an effort to improve and expand the programs that monitor fishing. These actions, together with the support of researchers, will ensure more accurate information on the fishing operations and the species captured. Additionally, the use of novel techniques (BRUVs, baited remote underwater video systems) helps to improve our understanding of distributions, ecology and behaviour of marine fauna (Wellington et al. 2016), for example in cases of poorly known and vulnerable species such as the ragged-tooth shark.

\section{Acknowledgements}

The authors thank the fishermen R. Hernandez and A. Hernandez who donated the jaw of $O$. ferox to the Centro para la Investigación de Tiburones (CIT) of Venezuela. We are also grateful to H. Ramirez for the photographic images used in this study and A.G. Gutiérrez for his assistance with digital processing of images. Finally, we especially thank Dr. A. Grant and anonymous referees for your helpful comments and suggestions to improve the manuscript.

\section{Authors' contributions}

RT organized the co-authors, wrote the manuscript, and prepared the final maps and images. LS measured the teeth, analyzed data, and gave technical assistance in photographic sessions. JMB received the shark jaw from fishermen and interviewed the captain of the fishing boat. All authors read and approved the final manuscript.

Funding

Not applicable.

\section{Availability of data and materials}

All data generated during this study are included in this published article. The dry jaw of the examined specimen (Odontaspis ferox) was deposited (under the code number CIT 1-037) in the jaw collection of the Centro para la Investigación de Tiburones (CIT), Caracas Venezuela.

Ethics approval

Not applicable.

Consent for publication

All authors consent to publication.

\section{Competing interests}

The authors declare that they have no competing interests.

\section{Author details}

${ }^{1}$ Centro para la Investigación de Tiburones (CIT), Av. Don Bosco, Qta ABC, No. 10, La Florida, Distrito Capital, Caracas 1050, Venezuela. ${ }^{2}$ Instituto Venezolano de Investigaciones Científicas (IVIC), Av. Panamericana km 11, San Antonio de los Altos, Estado Miranda 1204, Venezuela. ${ }^{3}$ Fundación Provita, Urbanización Augusto Malavé, Av. 9, No. 15, Boca de Rio, Isla de Margarita, Estado Nueva Esparta 6304, Venezuela.

Received: 22 July 2019 Accepted: 2 October 2019

Published online: 29 October 2019

\section{References}

Anguila R, Nieto-Alvarado LE, Hernández-Beracasa L. Nuevos registros de peces de esqueleto cartilaginoso para el Caribe colombiano y uno como ampliación de su distribución geográfica en el Caribe colombiano para Bocas de Ceniza, departamento de Atlántico, Colombia. Bol Invest Mar Cost. 2016:45(2):361-73.

Baum JK, Myers RA. Shifting baseline collapse and the decline of pelagic sharks in the Gulf of Mexico. Ecol Lett. 2004. https://doi.org/10.1111/j. 1461-0248.2003.00564.x.

Bonfil R. Is the ragged-tooth shark cosmopolitan? First record from the western North Atlantic. J Fish Biol. 1995. https://doi.org/10.1111/j.1095-8649.1995. tb01902.x.

Castellanos P, Varela R, Muller-Karger F. Descripción de las áreas de surgencia al sur del Mar Caribe examinadas con el sensor infrarrojo AVHRR. Mem Fund La Salle Cienc Nat. 2002:154:55-76.

Clarke S, Milner-Gulland EJ, Bjørndal T. Social, economic, and regulatory drivers of the shark fin trade. Mar Resour Econ. 2007. https://doi.org/10.1086/mre.22.3. 42629561. 
Compagno LJV. Sharks of the world: an annotated and illustrated catalogue of shark species known to date. FAO Species Catalogue for Fishery Purposes: Rome; 2(1) 2001.

Dulvy NK, Fowler SL, Musick JA, Cavanagh RD, Kyne PM, Harrison LR, Carlson JK, Davidson LN, Fordham SV, Francis MP, Pollock CM, Simpfendorfer CA, Burgess GH, Carpenter KE, Compagno LJV, Ebert DA, Gibson C, Heupel MR, Livingstone SR, Sanciangco JC, Stevens JD, Valenti S, White WT. Extinction risk and conservation of the world's sharks and rays. eLife. 2014. https://doi. org/10.7554/eLife.00590.001.

Fergusson IK, Graham KJ, Compagno LJV. Distribution, abundance and biology of the smalltooth sandtiger shark Odontaspis ferox (Risso, 1810) (Lamniformes: Odontaspididae). Environ Biol Fish. 2008. https://doi.org/10. 1007/s10641-007-9193-X.

Ferretti F, Worm G, Britten GL, Heithaus MR, Lotze HK. Patterns and ecosystem consequences of shark declines in the ocean. Ecol Lett. 2010. https://doi.org/ 10.1111/j.1461-0248.2010.01489.x.

Garla RC, Garcia J. Occurrence of the ragged-tooth shark, Odontaspis ferox, at Fernando de Noronha archipelago, western equatorial Atlantic. Mar Biodivers Rec. 2008. https://doi.org/10.1017/S1755267206003952.

Garrick JAF. First record of an odontaspidid shark in New Zealand waters. NZ J Mar Freshw Res. 1974. https://doi.org/10.1080/00288330.1974.9515532.

Graham KJ, Pollard DA, Gordon I, Williams S, Flaherty AA, Fergusson I, Dicken M. Odontaspis ferox. In: The IUCN Red List of Threatened Species, vol. 2016; 2016. https://doi.org/10.2305/IUCN.UK.2016-1.RLTS.T41876A2957320.en. Accessed 20 June 2019.

Heupel MR, Knip DM, Simpfendorfer CA, Dulvy NK. Sizing up the ecological role of sharks as predators. Mar Ecol Prog Ser. 2014. https://doi.org/10.3354/ meps10597.

Jackson JBC, Kirby MX, Berger WH, Bjorndal KA, Botsford LW, Bourque BJ, Bradbury RH, Cooke R, Erlandson J, Estes JA, Hughes TP, Kidwell S, Lange CB, Lenihan HS, Pandolfi JM, Peterson CH, Steneck RS, Tegner MJ, Warner TR. Historical overfishing and the recent collapse of coastal ecosystems. Science. 2001. https://doi.org/10.1126/science.1059199.

McConnell MC, Thunell RC, Lorenzoni L, Astor Y, Wright JD, Fairbanks R. Seasonal variability in the salinity and oxygen isotopic composition of seawater from the Cariaco Basin, Venezuela: Implications for paleosalinity reconstructions: Geochem, Geophys, Geosyst; 2009. https://doi.org/10.1029/2008GC002035.

Menni RC, Hazin FHV, Lessa RPT. Occurrence of the ragged-tooth shark, Odontaspis ferox, in the western equatorial Atlantic. Chondros. 1995:5:3-4.

Muller-Karger F, Varela R. Influjo del Río Orinoco en el Mar Caribe: Observaciones con el CZCS desde el espacio. Mem Soc Cienc Nat La Salle. 1990;50:361-90.

Ross SW, Quattrini AM. The fish fauna associated with deep coral banks off the southeastern United States. Deep-Sea Res I. 2007. https://doi.org/10.1016/j. dsr.2007.03.010

Rueda-Roa DT, Muller-Karger FE. The southern Caribbean upwelling system: sea surface temperature, wind forcing and chlorophyll concentration patterns. Deep-Sea Res I. 2013;78:102-14.

Santander-Neto J, Faria W, Castro ALF, Burgess GH. New record of the rare ragged-tooth shark, Odontaspis ferox (Chondrichthyes: Odontaspidae) from the south-West Atlantic identified using DNA bar coding. Mar Biodivers Rec. 2011. https://doi.org/10.1017/S1755267211000698.

Sheehan TF. First record of the ragged-tooth shark, Odontaspis ferox, off the U.S. Atlantic coast. Mar Fish Rev. 1998;60:33-4 doi:aquaticcommons.org/ id/eprint/9807.

Tavares R, Arocha F. Species diversity, relative abundance and length structure of oceanic sharks caught by the Venezuelan longline fishery in the Caribbean Sea and western-Central Atlantic. Zootec Trop. 2008;26(4):489-503.

Wellington CM, Wakefield CB, White WT. First record of Odontaspis ferox (Risso, 1810) in the temperate South-Eastern Indian Ocean from in situ observations in a deep-water canyon using baited video. J Appl Ichthyol. 2016. https://doi. org/10.1111/jai.13190

\section{Publisher's Note}

Springer Nature remains neutral with regard to jurisdictional claims in published maps and institutional affiliations.

Ready to submit your research? Choose BMC and benefit from:

- fast, convenient online submission

- thorough peer review by experienced researchers in your field

- rapid publication on acceptance

- support for research data, including large and complex data types

- gold Open Access which fosters wider collaboration and increased citations

- maximum visibility for your research: over $100 \mathrm{M}$ website views per year

At BMC, research is always in progress.

Learn more biomedcentral.com/submissions 